\title{
Cell Biology of the Endoplasmic Reticulum and the Golgi Apparatus through Proteomics
}

\author{
Jeffrey Smirle ${ }^{1}$, Catherine E. Au ${ }^{1}$, Michael Jain ${ }^{2}$, Kurt Dejgaard ${ }^{1}$, Tommy Nilsson ${ }^{1}$, \\ and John Bergeron ${ }^{1}$ \\ ${ }^{1}$ The Research Institute of the McGill University Health Centre and the Department of Medicine, McGill \\ University, Montreal, Quebec H3A 1A1, Canada \\ ${ }^{2}$ University of Toronto, Division of Hematology, Toronto, Ontario M5G 2M9, Canada \\ Correspondence: john.bergeron@mcgill.ca
}

\begin{abstract}
Enriched endoplasmic reticulum (ER) and Golgi membranes subjected to mass spectrometry have uncovered over a thousand different proteins assigned to the ER and Golgi apparatus of rat liver. This, in turn, led to the uncovering of several hundred proteins of poorly understood function and, through hierarchical clustering, showed that proteins distributed in patterns suggestive of microdomains in cognate organelles. This has led to new insights with respect to their intracellular localization and function. Another outcome has been the critical testing of the cisternal maturation hypothesis showing overwhelming support for a predominant role of COPI vesicles in the transport of resident proteins of the ER and Golgi apparatus (as opposed to biosynthetic cargo). Here we will discuss new insights gained and also highlight new avenues undertaken to further explore the cell biology of the ER and the Golgi apparatus through tandem mass spectrometry.
\end{abstract}

$M$ ost biosynthetic proteins destined for the plasma membrane and secretion, as well as resident proteins of endosomes, lysosomes, the endoplasmic reticulum (ER), and the Golgi apparatus originate with cotranslational translocation into the ER. This is followed by carefully controlled folding and quality control. The ER is also a major site for sensing cellular stress and for cholesterol and phospholipid biosynthesis and constitutes a vast continuous endomembrane system that often pervades the entire cytoplasm. The ER commences as the nuclear envelope extends to rough (ribosome-studded) membranes, and ends with tripartite-like structures of tubular smooth (ribosome-free) ER.

The ratio of rough and smooth ER is cell type specific. Stem cells have little rough ER and smooth ER (Murphy et al. 1971; Cheng and Leblond 1974), whereas cells highly specialized in protein secretion, such as in the exocrine pancreas, have extensive rough ER with little to no smooth ER (Palade and Siekevitz 1956; Jamieson and Palade 1967). By contrast, liver parenchymal hepatocytes have a near equal abundance of rough and smooth ER with the latter associated with glycogen storage and elimination

Editors: Susan Ferro-Novick, Tom A. Rapoport, and Randy Schekman

Additional Perspectives on The Endoplasmic Reticulum available at www.cshperspectives.org

Copyright (C) 2013 Cold Spring Harbor Laboratory Press; all rights reserved; doi: 10.1101/cshperspect.a015073

Cite this article as Cold Spring Harb Perspect Biol 2013;5:a015073 
J. Smirle et al.

of exogenous steroids through a multitude of P450-driven oxidation pathways (Bruni and Porter 1965; Loud 1968; Estabrooket al. 1971; Blouin et al. 1977; Reed and Backes 2012). At the other extreme, Leydig cells of the testis are specialized in cholesterol metabolism to form testosterone and are enriched with smooth ER (Mori and Christensen 1980). Emanating from the ER of all cell types in mammals are discrete export sites that are distributed throughout the cell, sometimes numbering in the hundreds. ER export is controlled by the COPII coat machinery, which has been characterized through proteomics analyses in yeast (Otte et al. 2001) and is coupled to microtubule- and dynein/dynactin-dependent transport directed toward the central juxta-nuclear Golgi apparatus (COPII vesicles are discussed in Lord et al. [2013]). This occurs in vesicular/tubular clusters (VTCs) that seemingly undergo a maturation/distillation process (Saraste and Kuismanen 1984) such that when arriving at the cis-face Golgi stacks, biosynthetic cargo appears more concentrated. This is achieved, at least in part, through a continuous removal of ER export machinery components (e.g., p58, p24, and SNARE proteins) that are then returned to the ER via vesicular transport intermediates controlled by the COPI coat machinery. This apparent "distillation" process continues throughout the secretory pathway from as far as the trans-part of the Golgi apparatus (Miesenbock and Rothman 1995). Whether or not such distillation occurs through intraGolgi cisternal transport or through direct delivery to the ER is part of ongoing investigation, including the extent of recycling (see below).

The Golgi apparatus is morphologically distinct from the ER because of its juxtanuclear position, and at the ultrastructural level, appears as a ribbon-like structure of laterally interconnected stacks of flattened cisternae, each having a network of extensive fenestrated membranes associated both at their cis- and transface. Biosynthetic cargo here, undergo extensive posttranslational modifications including the maturation of $\mathrm{N}$-linked oligosaccharides, and the addition of $\mathrm{O}$-linked oligosaccharides. At the trans-face, cargo is sorted and packaged for transport either to the plasma membrane or to the endosomal endomembrane system. Some specialized cargo is also packaged and concentrated into dedicated membrane structures for regulated secretion.

The functional and morphological demarcation between the ER and the Golgi apparatus is usually assumed to be complete, giving rise to the notion of two independent organelleseach with their own distinct functions. Because of the extensive recycling that takes place, however, the two organelles appear functionally intertwined. Indeed, inhibition of the Golgilocated ARF1 guanine nucleotide exchange factor GBF1 results in a rapid collapse of the Golgi apparatus into the ER (Misumi et al. 1986; Oda et al. 1987; Fujiwara et al. 1988; LippincottSchwartz et al. 1989; Claude et al. 1999). As $A R F 1^{\mathrm{GDP}}$ to $\mathrm{ARF} 1^{\mathrm{GTP}}$ conversion is obligatory to COPI recruitment and vesicle formation and subsequent recycling, the effect of BFA seems at first counter intuitive, but can be explained through the additional role of COPI as a protective coat on cisternal membranes, i.e., BFAinduced dissociation of COPI coat from Golgi membranes enables uncontrolled formation of Golgi-derived tubules that within minutes fuse with the ER, collapsing most of the Golgi into the ER. Strikingly, removal of BFA equally rapidly leads to the reformation of individual functional Golgi stacks positioned at the various ER exit sites and after microtubule-dependent transport, coalesce into the central and juxtanuclear Golgi apparatus. Thus, the two organelles are temporally as well as spatially linked to enable productive communication and trafficking for the process of protein secretion, as well as lipid biosynthesis. This link gives rise to some unexpected functions (see below).

\section{ORGANELLE ISOLATION AND MASS SPECTROMETRY}

Isolation of the ER and Golgi apparatus from cultured cells, as well as the parenchyma of organs, has been well documented (Schneider et al. 1953; Ernster et al. 1962; De Duve and Beaufay 1981; Balch et al. 1984; Gilchrist et al. 2006). This led to the uncovering of the molecular machinery for protein translocation across membranes 
ER-Golgi Proteomics

(Blobel and Dobberstein 1975), the machines for protein folding and processing (De Lorenzo et al. 1966; Haas and Wabl 1983), and the machines for the egress of newly synthesized protein out of the ER for further processing and sorting in the Golgi apparatus (Zanetti et al. 2012). In this way, our knowledge base of the translocon, cotranslational transport of proteins across the ER membrane, the role of molecular chaperones, and the various coats and GTPases regulating the structure and functions of the ER and Golgi apparatus has been built.

For organelles, as for any other characterization methodology (EM, marker enzyme, western blot enrichment), organelle enrichment and assessment of degree of homogeneity is a criterion well accepted by the subcellular fractionation community. For the ER and Golgi apparatus, electron microscopy (especially of samples processed by the Baudhuin filtration apparatus [Baudhuin et al. 1967]) enables a random view of degree of homogeneity, which is further documented by morphometry. For our studies at least, isolated organelles are denatured and the proteins are solubilized in SDS, followed by 1-D SDS PAGE. The ensuing gel lanes are then divided into 1-2 mm slices, sliced into smaller cubes, and subjected to in-gel trypsin digestion. Eluted peptides are then available for characterization through tandem mass spectrometry (LC-MS/ MS). Subcellular fractionation and SDS-PAGE both contribute to a necessary decomplexing of the sample, enabling maximum coverage of protein content. Further decomplexing can be achieved through biochemical fractionation (e.g., phase separation through TX114 to enrich for membrane-bound proteins, or salt wash of membranes) (Gilchrist et al. 2006; Au et al. 2007). When performed quantitatively, assignment of proteins to their cognate organelle is achieved as an additional outcome, along with direct estimates of protein contamination from other membrane structures, cytosol, and the extracellular space. For proper identification and assignment of the multitude of proteins contained in each organelle; however, mass spectrometry data needs to be matched to databases, and this seemingly simple step is not as straightforward as one would think.

\section{PEPTIDE MATCHING}

As shown with the distribution of 20 equimolar, highly purified human test proteins sent to 27 different international labs, regardless of the mass spectrometer and software used to match tandem mass spectra from fragmented tryptic peptides to cognate peptide sequences, the match is usually (but not always) failsafe; however, subsequent matching to cognate proteins remains difficult. Indeed, of the 27 labs, only seven were able to do this correctly (Bell et al. 2009). This was not because the quality of the tandem mass spectra generated was poor. Rather, inadequacies in databases and software for matching peptides to proteins were mainly at fault. Even today, databases remain a major hurdle for large-scale projects that depend on the characterization of proteins by mass spectrometry. When organelles are added to the mix, the data can be overwhelming in complexity. The NCBI nonredundant database has the advantage of being the most complete and annotated for nonhuman sequences, but unfortunately, uses accession numbers that change or are discontinued. As with the proteomes of the ER and the Golgi apparatus (Gilchrist et al. 2006), the community has a hard time taking full advantage of the study as this requires painstaking (manual) updating of old accession numbers to new ones. As a consequence, large-scale proteomics studies often end up as data cemeteries with zero value to the community. Other databases, such as Uniprot, are easier to handle, but such databases are usually incomplete (especially for rodents) (Bergeron et al. 2010). The best curated and most highly annotated database for human proteins is currently the Swiss-based NeXtProt, which, hopefully, will retain their accession numbers over time, thus ensuring the value of proteomics studies to the community. Another hurdle is encountered with proteins having related sequences (e.g., small GTPases, P450s), which are each encoded by individual genes. Search engines do not yet distinguish between peptides shared between closely related proteins and those that are proteotypic giving rise to a multitude of erroneous assignments. For variants (isoforms, splice 
J. Smirle et al.

variants, SNPs) encoded by the same gene, BLAST is currently the only safe way to achieve correct assignment of peptide sequences to the cognate protein.

\section{QUANTITATIVE PROTEOMICS}

For the cell biologist, visualization of the frequency of peptides assigned to specific sequences affords a ready assessment as to not only the protein identity, but also a very good approximation of its relative abundance (Fig. 1). Initially thought of as a qualitative method, tandem mass spectrometry is now considered highly quantitative. Although specialized methods exist for quantification (often through ad- dition of heavy isotope labeled peptides, culturing cells in the presence of heavy isotope labeled amino acids, or feeding rodents heavy isotopes (Smolka et al. 2001; Ong et al. 2002; von Haller et al. 2003; Kruger et al. 2008; Graumann et al. 2012; Zeiler et al. 2012), so-called label free quantification often suffices and is convenient and remarkably accurate. Counting the number of tandem mass spectra assigned to a peptide in cognate proteins is one such method, referred to as redundant peptide counting or spectral counting (Gilchrist et al. 2006; Bergeron and Hallett 2007). The other is through the ion currents carried by the peptides unique to each protein (Campbell-Valois et al. 2012; Ludwig et al. 2012). Either method is applicable,

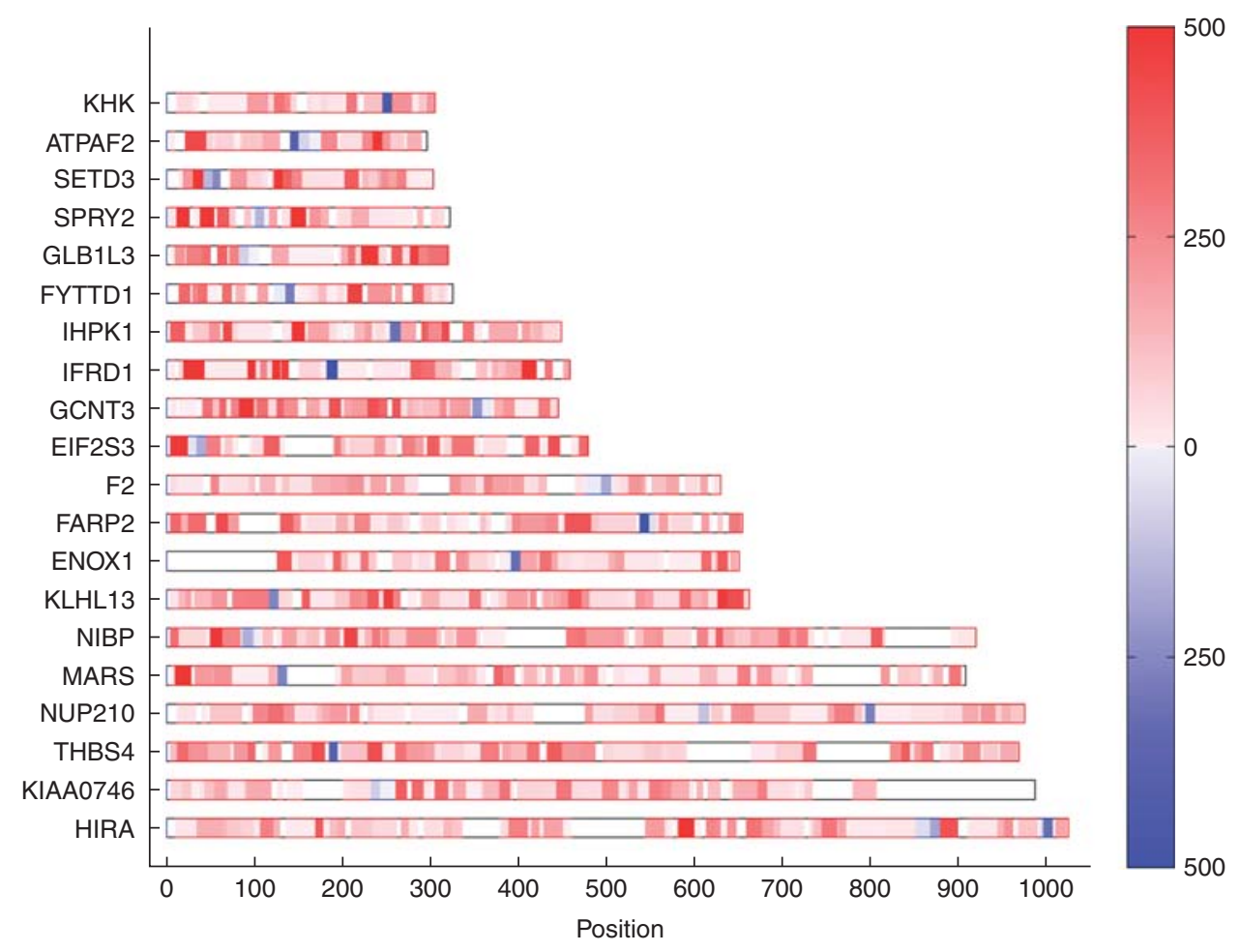

Figure 1. Quantitative proteomics of 20 recombinant human proteins. Frequency of tandem mass spectra assigned to tryptic peptides in 20 recombinant human proteins (gene symbol). The results are shown as a peptide heat map representation for each of the 20 proteins. Each protein was present at equimolar abundance in the mixture. Intensity of red indicates abundance of tryptic peptides characterized by tandem mass spectrometry. Blue represents a tryptic peptide of $1250 \mathrm{Da}$. Each of the 20 proteins contained one or more peptides of this mass, but of a different primary sequence. Abscissa scale indicates the number of amino acid residues. (From Bell et al. 2009; reprinted, with permission, from the author and Nature Publishing Group (C 2009.) 
ER-Golgi Proteomics

although redundant peptide counting appears to be more universally employed. The typical dynamic range achieved through redundant spectra counting is about three orders of magnitude. Ion current intensity offers (in theory) a higher dynamic range, but is limited in its lack of resolution of the peak base and the stochastic assignment of the highest peak, still a feature of most mass spectrometers even today. The ideal would be a combination of the two, deploying full peak area integration, yet this seemingly obvious feature is still missing. Nevertheless, label-free quantification (as applied) is sufficiently powerful to enable cell biologytype discoveries as shown in key papers (Blondeau et al. 2004; Cox et al. 2005; Gilchrist et al. 2006; Kislinger et al. 2006; Silva et al. 2006) and below.

\section{HIERARCHICAL CLUSTERING}

After matching the tandem mass spectra to cognate proteins, these can then be sorted conveniently using the same type of programs as developed to cluster microarray data. As seen in Figure 2A for isolated rough microsomes, smooth microsomes, Golgi fractions, and Golgi-derived COPI vesicles from rat liver homogenates, this enables a ready visualization of which proteins are enriched in which samples. It also enables the visualization of which subsets of proteins codistribute. Because there are more subsets of proteins that codistribute than there are organelles, this predicts the presence of microdomains through codistributing proteins. Using a Pearson coefficient of correlation of $>0.90$, we predict that as many as 24 such microdomains may be present in the ER, Golgi, and COPI vesicles. Functionality of these microdomains can be inferred when clusters containing proteins involved in translation, translocation, protein folding, and ER-associated degradation (ERAD) are analyzed (Fig. 2B). For example, when ERAD constituents are visualized through proteomics, they segregate into the smooth ER compartments, easily distinguished from the translocon and translation-associated proteins, as proposed previously by other studies (Groisman et al. 2011).

\section{EXPANDING THE ER-GOLGI AXIS OF FUNCTIONAL INTERRELATIONSHIP}

Visualization of one such subset of codistributing proteins was the first indication that the protein folding enzyme ERp44 codistributes with Golgi resident proteins (Fig. 3A) (Gilchrist et al. 2006). This was unexpected as previous studies showed an ER localization, as would be expected for a soluble lumenal protein with a cleaved signal peptide and carboxy-terminal KDEL sequence. Indeed, localization of an ERp44-EGFP fusion placed this squarely in the ER, with little of the protein being present in the Golgi apparatus (Anelli et al. 2002, 2003). Comparative quantitative mass spectrometry data, however, suggested the opposite (Gilchrist et al. 2006). Indeed, using a mono-specific antibody to ERp44 provided by P. Scherer (UT Southwestern), we were able to confirm its proteomics-based Golgi localization through indirect immunofluorescence (Fig. 3C). Most investigators now agree that ERp44 is located in the Golgi apparatus in most cells and this has enabled a functional elucidation of a vital mechanism that depends on the ER-Golgi interface (Fraldi et al. 2008; Mariappan et al. 2008). The Golgi location for ERp44 and its retrograde trafficking also explains its function as a proteinfolding enzyme, protein disulfide reductase, specific for the last interchain disulfide bonding of oligomers such as polymeric Ig (Cortini and Sitia 2010).

Another protein surprisingly assigned to the Golgi through proteomics and confirmed to codistribute with Golgi markers is ER mannosidase I (Fig. 3B). This protein catalyzes the removal of the outermost mannose residue on the B-chain of high mannose $N$-linked glycoproteins generated in the ER (Gonzalez et al. 1999). Although not noticed in our original resource, Pan et al. (2011), showing a Golgi location with a monoclonal antibody to the protein, prompted reexamination of the resource. The assigned LCMS/MS data clearly indicates a Golgi location. It is further highly concentrated in functional Golgi-derived COPI vesicles generated under conditions in which GTP hydrolysis is permitted (Lanoix et al. 1999) but not in vesicles generated 
J. Smirle et al.
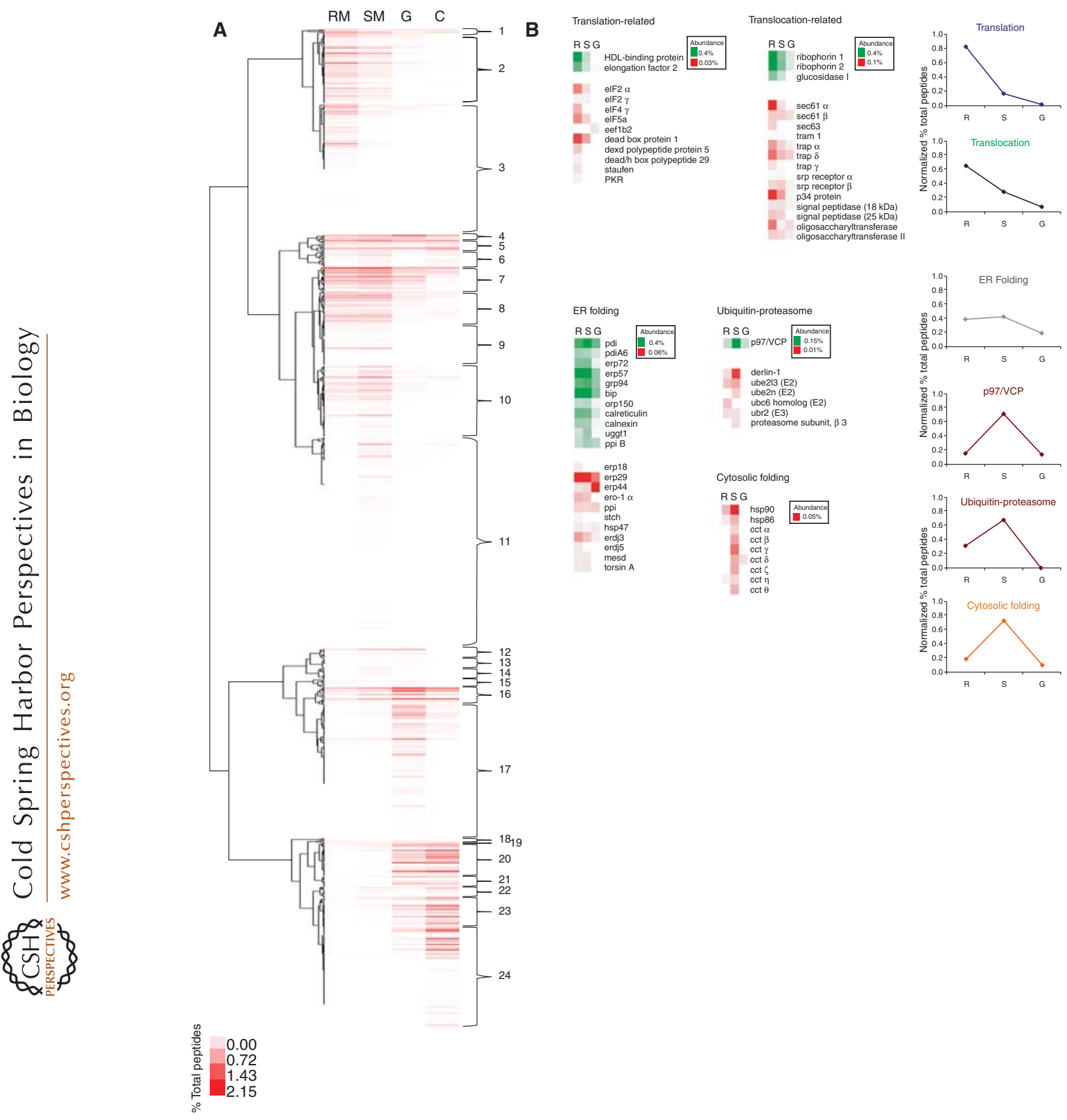

Figure 2. Hierarchical clustering and identification of ER microdomains. (A) Hierarchical clustering of 1146 proteins characterized in isolated rat liver rough microsomes (RM), smooth microsomes (SM), Golgi (G), and COPI vesicle (C) fractions, as described in Gilchrist et al. (2006). 24 different clusters of proteins are identified. (B) Selected proteins related to translation, translocation, ER folding, ERAD ( p97, ubiquitin-proteasome), and cytosolic folding are shown. The relative distribution of the proteins is indicated (abundance) as a percent of total peptides. 
A

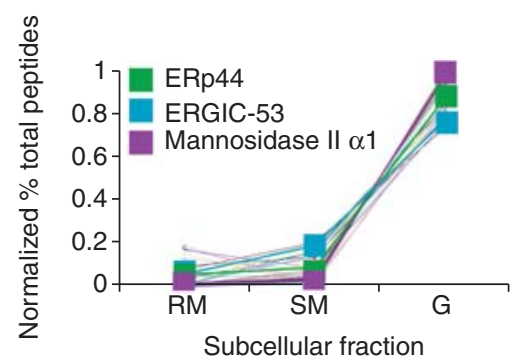

B

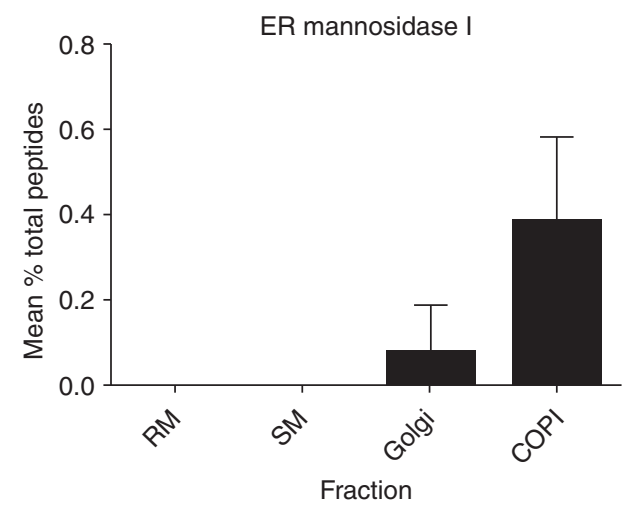

C

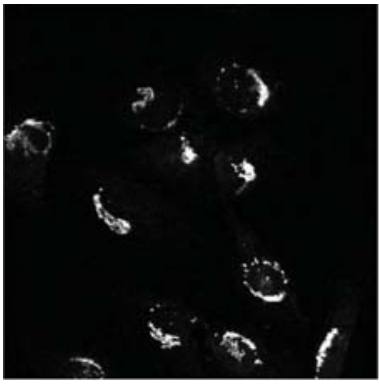

GM130

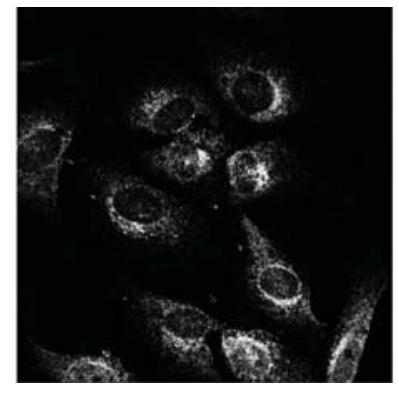

ERp44

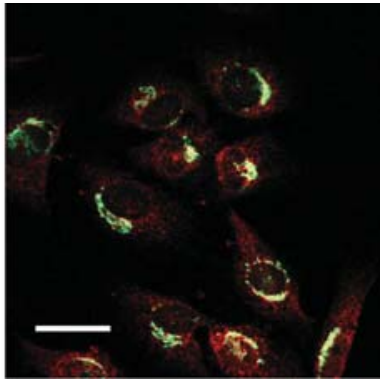

Merged

Figure 3. Predicted ER proteins uncovered in the Golgi apparatus. (A) Codistribution of the PDI family member ERp44 with mannosidase II and ERGIC-53. (B) Distribution of ER mannosidase I in isolated RM, SM, Golgi, and COPI vesicle fractions. $(C)$ Colocalization of ERp44 with the Golgi marker GM130. Scale bar, $25 \mu \mathrm{m}$. (From Gilchrist et al. 2006 and the supplement of Gilchrist et al. 2006; reprinted, with permission, from Elsevier Ltd. C 2006.)

in the presence of nonhydrolysable GTP. ER mannosidase I also appeared absent in both rough and smooth ER membranes. As with ERp44, the substrates of the enzyme (high-mannose linked $N$ glycoproteins) are in the ER. A retrograde trafficking step to bring the enzyme to its substrate could assure that this mannosidase action is restricted to mature $N$-linked glycoproteins in the ER or for ERAD (Pan et al. 2011), further extending the ER-Golgi axis of functional interrelationships.

\section{THE CALNEXIN CYCLE AS EXTENDED ER MICRODOMAINS}

The overall coordination of folding of $N$-linked glycoproteins in the ER is regulated by the calnexin cycle (Ou et al. 1993; Ellgaard and Helenius 2003). Briefly, newly synthesized $N$-linked glycoproteins are glycosylated with 14 sugars donated from a dolichol-linked lipid via oligosaccharyl transferase (Das and Heath 1980). Following the sequential removal of the terminal glucose by glucosidase I (Hettkamp et al. 1984; Bause et al. 1989), the glycoprotein may then be recognized by the protein malectin (Schallus et al. 2008; Chen et al. 2011; Galli et al. 2011), potentially for presentation to glucosidase II for removal of the second glucose residue (Burns and Touster 1982; Reitman et al. 1982; Pelletier et al. 2000). The resulting mono-glucosylated glycoprotein is then a client for association with calnexin or calreticulin (Hammond et al. 1994; Zapun et al. 1997; Schrag et al. 2003). These proteins shelter the polypeptide of the glycoprotein beneath an extended arm made of three (calreticulin) to four (calnexin) tandem repeats of hydrophobic residues and proline 
J. Smirle et al.

residues arranged in a hairpin (Schrag et al. 2001). This sequesters the partially folded newly synthesized glycoprotein as a monomer, and allows for the action of the PDI ERp57 (Zapun et al. 1998), itself in association with the extended arm (Pollock et al. 2004). The glycoprotein associates and dissociates with calnexin/calreticulin until its stable folding conformation is achieved. During dissociation, competition with soluble glucosidase II enables a stochastic removal of the terminal glucose in competition with reassociation with calnexin (Zapun et al. 1997; Chevet et al. 2010). If the unglucosylated glycoprotein is folded, it moves on for mannosidase processing by ER man I or for reglucosylation by a soluble lumenal protein folding sensor termed UDP-glucose denatured glycoprotein glucosyl-transferase (UGGT), for another round of calnexin/calreticulin association (Taylor et al. 2003, 2004; Trombetta and Parodi 2003). This is repeated multiple times until productive folding is complete (Zapun et al. 1997) or terminated through a channeling of the glycoprotein to degradation, a process initiated by the HTM1/EDEM complex removing the C-chain mannose of the $\mathrm{N}$-glycan and through the lectin OS9, to the endoplasmic reticulumassociated protein degradation (ERAD) machinery (Molinari et al. 2003; Szathmary et al. 2005; Christianson et al. 2008; Clerc et al. 2009; Groisman et al. 2011). The glycoprotein to be degraded is first subjected to Sec61-dependent and presumably, a derlin machinery-dependent retrotranslocation followed by a p97 ATPase complex-dependent import into the proteasome for degradation (Lilley and Ploegh 2004, 2005; Wahlman et al. 2007; Stolz et al. 2011). The distribution of the proteins of the calnexin cycle in isolated rough and smooth ER, Golgi, and COPI fractions is shown in Figure 4 (data from Gilchrist et al. 2006). Mapping the distribution of tandem mass spectra for each protein of the calnexin cycle reveals a progression of the maximum concentrations of each protein, from mainly rough ER (for sec61, the ribophorins, glucosidase I, and malectin- corresponding to clusters 2 and 3 in Fig. 2A) to equal concentrations in rough and smooth (for calnexin, calreticulin, and ERp57 clusters 7 and 8 in Fig. 2A), to more enriched in smooth ER (Glucosidase II, UGGT cluster 10 in Fig. 2A), and finally Golgi (ERp44 cluster 23 in Fig. 2A), thereby recapitulating the spatial and temporal aspects of folding and glycoprotein-dependent quality control.

There were several proteins observed for the first time at the protein level in the Gilchrist et al. (2006) resource. By combining database searches from other large-scale projects in various organisms, it is possible to gain further insight into the functions of some of these novel proteins. For example, a screen for genes that affect IRE1 expression (a sensor for the unfolded protein response; see Gardner et al. [2013] for more information on IRE1) in yeast (S. cerevisiae) uncovered a new protein complex termed the ER membrane protein complex (EMC). The EMC was shown to be comprised of six integral membrane proteins postulated to regulate quality control of newly synthesized integral membrane proteins (Jonikas et al. 2009). As shown in Figure $5 \mathrm{~A}$, when the rat homologs are mapped, the proteins are found in abundance in which, as expected, the higher molecular weight proteins reveal more tandem mass spectra than the low molecular weight ones. All six members of the complex reside largely in the rough ER and all partition into the detergent Triton X-114, as predicted for integral membrane proteins (Fig. $5 \mathrm{~A})$. Hence, these proteins can now be reclassified along with their previously predicted human homologs (Jonikas et al. 2009). Because the complex is seen to be more enriched in rough ER than smooth ER, then a prediction is that the ER quality-control function of this complex may be close to or part of the translocon.

\section{PROTEIN CLASSIFICATION AND LESSONS LEARNED IN THE GOLGI APPARATUS}

Public databases (such as GO) attempt to gather proteins into classifications; however, our experience has been that this classification tends to be less informative than the categories we selected for the secretory pathway (Gilchrist et al. 2006). We found that 22 different categories enabled a comprehensive grouping of all the proteins in the ER-Golgi resource. When the comparison was made based on the relative 
ER-Golgi Proteomics
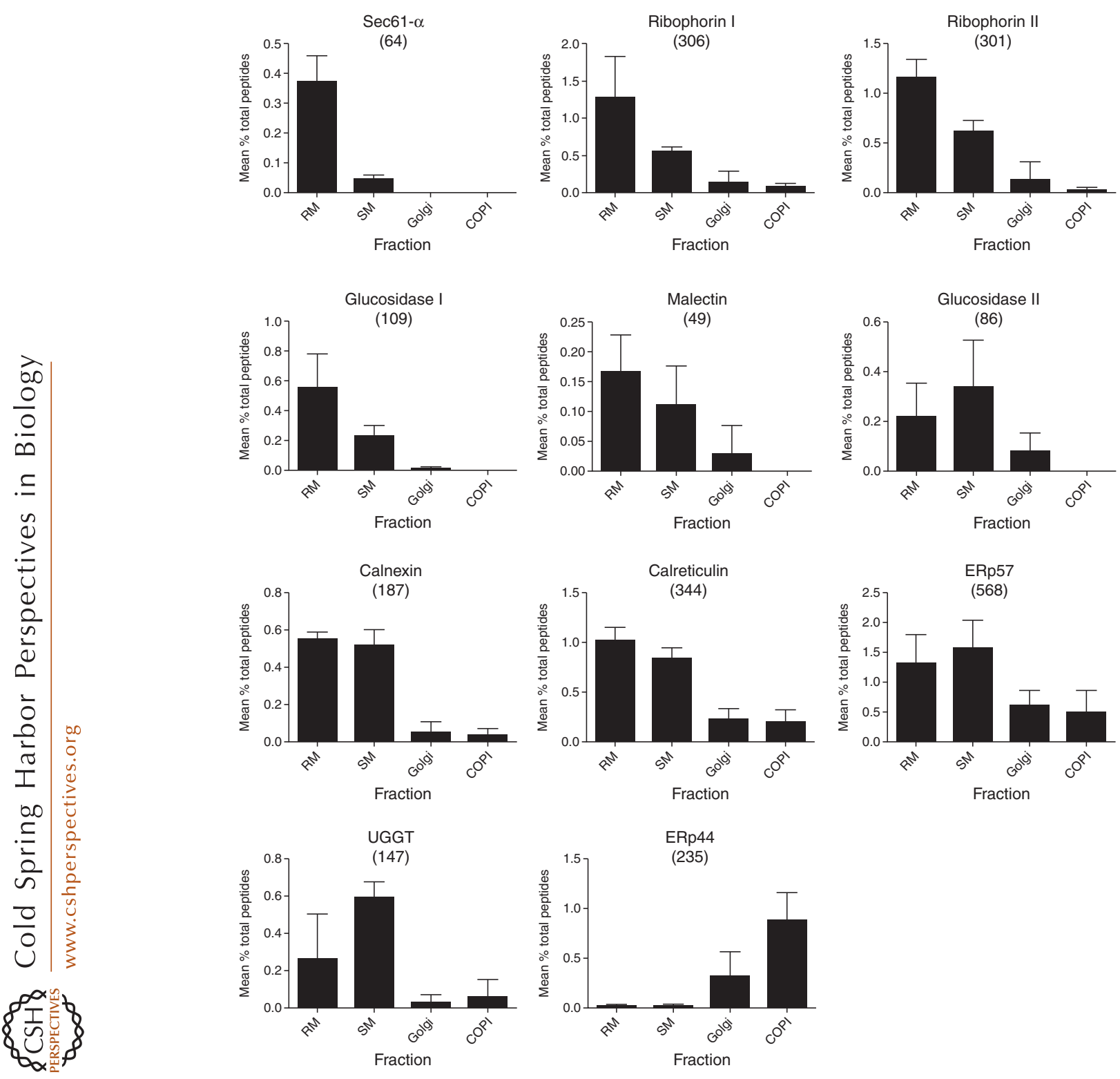

Figure 4. Proteomics of the calnexin cycle. Distribution of selected proteins related to the calnexin cycle. The relative distribution of each protein (mean \pm SD) is indicated. Total number of peptides identified for each protein is in parentheses above each histogram. (Data from supplement of Gilchrist et al. 2006.)

abundance of the proteins characteristic for each category, the secretory cargo family was immediately seen as enriched in the Golgi fraction (Fig. 5B). This supports earlier morphological studies showing the concentration of biosynthetic material as it progresses through the secretory pathway, with the highest concentra- tion seen in the interface between the ER and the Golgi apparatus, and with little or no further concentration across the Golgi stack (Dahan et al. 1994; Martinez-Menarguez et al. 1999; Oprins et al. 2001). There are striking examples of cargo condensation, however, also in the Golgi stack. Collagen formation studies (Grasse 
J. Smirle et al.

A

EMC

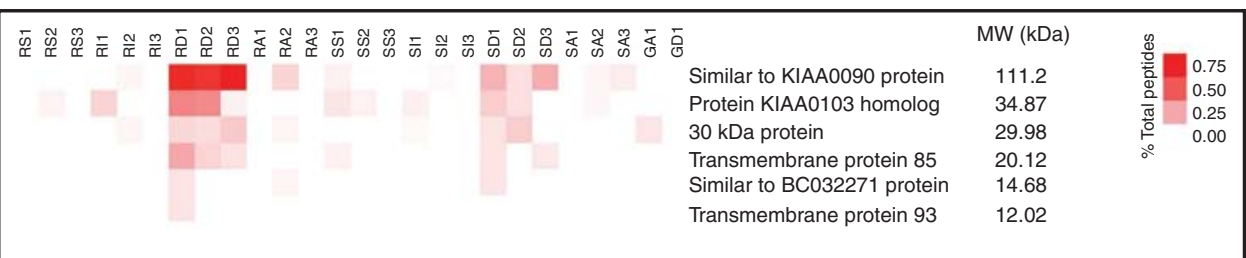

B

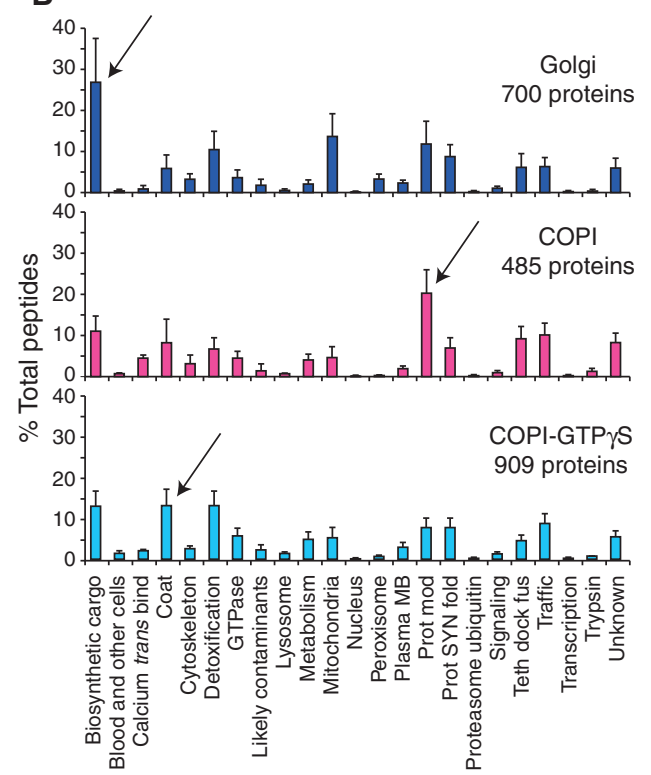

C Golgi resident proteins in COPI vesicles

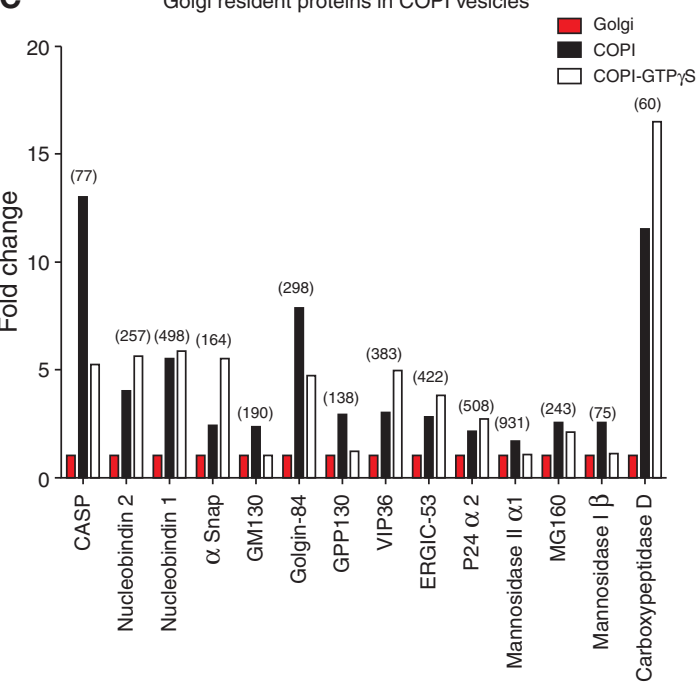

Protein

Figure 5. Proteomics discoveries within the ER and Golgi. (A) Rat homologs of the yeast EMC. Rough and smooth microsomes were subfractionated as described in Gilchrist et al. by salt wash (RS1-3 and SS1-3; for rough and smooth microsomes, respectively), followed by solubilization by the detergent Triton-X 114 . The integral membrane proteins partition into the detergent phase (RD1-3 and SD1-3). All six proteins, considered to be homologs of the yeast EMC proteins, are at highest abundance ( $\%$ total peptides) in the RD. Hence, the EMC proteins are concluded to be integral membrane proteins of the rough endoplasmic reticulum in rat liver. $(B)$ The proteins detected in the Golgi, COPI, and COPI-GTP $\gamma S$ fractions, as organized by functional categories. Arrows indicate functional categories that were most abundant in each fraction $(N=3$, means and SD shown). (Data from supplement of Gilchrist et al. 2006.) (C) Golgi resident proteins are enriched in COPI vesicles. When the proteins that increase in COPI vesicles versus the Golgi fraction were interrogated with the Gilchrist et al. (2006) resource, Golgi resident proteins were seen to be more abundant in the two COPI vesicle fractions (total number of peptides identified for each protein indicated in parentheses).

1957) and scale formation in certain algae (Melkonian et al. 1991) can be readily observed in Golgi stacks giving rise to intra-cisternal structures that are similar in size to the overall cisterna in a cis to trans direction. These studies constitute hallmark studies that argue in favor of the cisternal maturation/progression model for intra-Golgi transport. More recent work by Luini and colleagues confirms and affirms that procollagen traverses the Golgi stack without ever leaving the cisternae (Bonfanti et al. 1998). The question how intra-Golgi cargo condensation is driven is unclear, but presumably involves a gradual lowering of $\mathrm{pH}$ in a cis-trans direction, coupled with high $\mathrm{Ca}^{2+}$ and intrinsic condensation properties of the proteins themselves as 
observed for cargo proteins destined for regulated secretion (Mosley et al. 2007). With a continuous maturation and condensation of biosynthetic material taking place such that it remains within the lumenal space of the Golgi cisternae and the cisternae themselves move in a cis-to trans direction, the question is whether or not the resident components of the Golgi apparatus (e.g., SNARE proteins, glycosylation enzymes) move with the biosynthetic cargo. Quantitative immune-electron microscopy suggested that this was not the case showing that glycosylation enzymes seemed restricted to predominantly two (e.g., the medial and trans cisternae) but sometimes more cisternae, giving rise to distinct but overlapping distributions (Nilsson et al. 1993; Rabouille et al. 1995). In a cisternal maturation/progression scenario, this suggests extensive recycling of glycosylation enzymes such that these move, cisternae to cisternae, in the opposite direction to that of the biosynthetic cargo. Indeed, COPI vesicles are more enriched in Golgi resident proteins as exemplified by in the protein modification category (for COPI vesicles generated with hydrolysable GTP), whereas the COPI coat is most enriched in the COPI vesicle fraction generated with nonhydrolysable GTP. Interrogation of the data for those proteins, which increase in COPI vesicles over parent Golgi fractions, reveals that only Golgi residents are enriched (Fig. 5C). This directly supports the maturation model for Golgi transport as argued elsewhere (Nilsson et al. 2009; Bergeron et al. 2010; Nakano and Luini 2010; Gannon et al. 2011). An important note here is the combination of enriched Golgi membranes and the generation of vesicles using such membranes in vitro. As pointed out by de Duve, enrichment of the particulate as promoted by Palade may give rise to limitations if part of the particulate or structures associated with the particulate does not follow the enrichment of the main component. Enrichment of Golgi membranes is perhaps here a good example in which Golgi-derived COPI vesicles have distinct sedimentation properties compared to cisternal membranes. De Duve would have argued, and correctly so in this case, that gradient profiling is the preferred strategy if wanting to encompass cisternal Golgi membranes as well as smaller transport intermediates associated with the Golgi apparatus (e.g., COPI- and clathrin-coated vesicles). Another point made by de Duve was that a protein might reside in multiple locations and its activity not necessarily correlated with its main biological activity (e.g., ERp44).

\section{ALTERNATIVE STRATEGIES}

Adhering to the de Duve dictum, gradient profiling of whole cell extracts with the purpose of assigning proteins to their cognate organelle(s) has been attempted, albeit with somewhat limited success. Analytical fractionation through rate zonal (density) centrifugation separates organelles partially across the sucrose gradients. In proteomics, marker proteins were used to distinguish the sedimentation properties to define the organelle distributions in gradients (Dunkley et al. 2004). In an approach termed "protein correlation profiling" (PCP), Foster and coworkers (2006) attempted analytical fractionation of whole cell extracts, followed by assignment of detected proteins to cognate organelles. Because of the inherent limitation in dynamic range with the mass spectrometers used at that time, this limited the amount of low abundance proteins that could be assigned to the various organelles across the gradient. As, typically, the Golgi apparatus only makes up about 1\%-2\% of total membranes in a cell, the study is biased against proteins of this organelle. Indeed, only 19 genuine Golgi resident proteins were detected. In contrast, 48 proteins assigned to the Golgi apparatus by the PCP approach were contaminants. Kislinger and coworkers relied on another approach based on rate sedimentation centrifugation to separate organelles over a gradient (Kislinger et al. 2006). Again, the limited dynamic range of the mass spectrometers used prevented a comprehensive accounting of proteins. For example, the group resolved 12 cytochrome P450s in liver microsomes. By contrast, using enriched ER membranes in combination with triton X-114 extraction to enrich for membrane proteins enabled a total of 34 cytochrome P450s to be resolved along with their relative abundance (Gilchrist et al. 2006). With HPLCs 
J. Smirle et al.

that operate at higher pressure, peptides can now be separated to a much higher degree using longer columns packed with beads of smaller diameter. This results in a dramatic decomplexing of peptides eluted from the loading cartridge along with a sharpening of peaks giving rise to an improved signal-to-noise ratio and, hence, increased dynamic range. Using this approach, Geiger et al. (2012) identified up to 10,000 proteins from a cell extract in a single run showing the power of this method. Improvements in mass spectrometers themselves have also contributed to higher dynamic range. It will therefore be of interest to revisit PCP and variants thereof to evaluate the ability to correctly and comprehensively assign proteins to correct organelle(s).

Elucidation of protein-protein interactions provides new information through "guilt by association" and has proven successful at all levels of cell biology and biochemistry. When performed as global strategies, this should provide key information aiding in the functional elucidation of complete proteomes. This has been attempted in yeast through genetically engineered open reading frames to include proteinepitope tags that can be used to purify the protein along with its interactors. Another approach, termed top-down interactomics, uses native-gel electrophoresis followed by mass spectrometry to elucidate protein complexes in tissue or tissue culture extracts. In one such study, Dejgaard and coworkers succeeded in separating and characterizing the native ribosome-translocon complex from canine pancreas microsomes (Dejgaard et al. 2010). The native complex identified was larger than that predicted, and confirmed earlier work by Meyer and others (Hortsch et al. 1986; Savitz and Meyer 1990), showing that the p180/ribosome receptor is indeed a constituent of the ribosometranslocon complex. Additional components such as CLIMP63, glucosidase I, and BAP31 were also assigned to the ribosome-translocon complex giving rise to a native size of $4 \mathrm{MDa}$ rather than the previously predicted size of 2 MDa. When combined with software similar to that deployed in the PCP approach above, numerous protein complexes can now be ob- served in a given sample negating the need for eptitope tagging and affinity-based isolation. When dealing with human tissue, this offers a great advantage over conventional interactomics-based strategies.

\section{CONCLUSION AND OUTLOOKS}

The technological advances in mass spectrometry have allowed for reliable, quantitative identifications of the protein make-ups of a variety of subcellular organelles. The combination of quantitative mass spectrometry and hierarchical clustering algorithms predicts functional microdomains within the rough and smooth ER. The analysis of the constituents of the calnexin cycle reveals a spatial distribution of the proteins that is coincident with the progression of successive steps in productive glycoprotein folding. Because ER readily fragments during homogenization, the use of antibodies coupled to magnetic beads to isolate subdomains (as was used to reveal subpopulations of COPI vesicles [Lanoix et al. 2001]) may enable the isolation to homogeneity of predicted microdomains segregated into different fragments of ER. From what we have learned so far, it is safe to say that the ER and the Golgi are multitasking organelles acting not only in series, but also collaborate to enable novel mechanisms that require temporal and spatial separation such as that observed with ERp44 and possibly, ER mannosidase I. Other membrane interfaces such as the GERL in which ER cisternae interdigitates with the trans-most Golgi cisternae or associate with the phospholipid surface of mitochondria or lipid droplets are likely to provide interesting twists on mechanisms previously ascribed to either organelles (Novikoff and Yam 1978; Halter et al. 2007; English et al. 2009; Lynes et al. 2012). To underscore this notion, a subset of ER resident proteins have emerged as constituents of maturing phagosomes giving rise to a mechanistic basis for antigen cross presentation in innate immunity (Gagnon et al. 2002; Houde et al. 2003; Cebrian et al. 2011; Campbell-Valois et al. 2012). The ER also generates peroxisomes (Titorenko et al. 1997; Titorenko and Rachubinski 1998; van der Zand et al. 2012), and a further specialized 
subset of ER is found beneath the cell membrane of many cells (English et al. 2009). The Golgi apparatus, on the other hand, contributes part of its machinery to lipid droplet biogenesis, revealing a mechanistic link previously thought to be exclusive to that of the ER. Complete compendiums of ER and Golgi membranes along with a complete functional elucidation of each constituent have not yet been achieved and will require combinations of biochemistry, clever fractionation strategies, mass spectrometry, interactomics-based studies, immune-based localization, and genetic interference (e.g., knockdown or knockout). Technological advances will help in this continuous endeavor.

\section{ACKNOWLEDGMENTS}

We thank Richard Sifers (Baylor University) for information regarding ER mannosidase I. We also thank the CIHR for funding (Grant MOP 5605).

\section{REFERENCES \\ * Reference is also in this collection.}

Anelli T, Alessio M, Mezghrani A, Simmen T, Talamo F, Bachi A, Sitia R. 2002. ERp44, a novel endoplasmic reticulum folding assistant of the thioredoxin family. EMBO J 21: 835-844.

Anelli T, Alessio M, Bachi A, Bergamelli L, Bertoli G, Camerini S, Mezghrani A, Ruffato E, Simmen T, Sitia R. 2003. Thiol-mediated protein retention in the endoplasmic reticulum: The role of ERp44. EMBO J 22: 5015-5022.

Au CE, Bell AW, Gilchrist A, Hiding J, Nilsson T, Bergeron JJ. 2007. Organellar proteomics to create the cell map. Curr Opin Cell Biol 19: 376-385.

Balch WE, Dunphy WG, Braell WA, Rothman JE. 1984. Reconstitution of the transport of protein between successive compartments of the Golgi measured by the coupled incorporation of $N$-acetylglucosamine. Cell 39: 405-416.

Baudhuin P, Evrard P, Berthet J. 1967. Electron microscopic examination of subcellular fractions. I. The preparation of representative samples from suspensions of particles. $J$ Cell Biol 32: 181-191.

Bause E, Schweden J, Gross A, Orthen B. 1989. Purification and characterization of trimming glucosidase I from pig liver. Eur J Biochem 183: 661-669.

Bell AW, Deutsch EW, Au CE, Kearney RE, Beavis R, Sechi S, Nilsson T, Bergeron JJ. 2009. A HUPO test sample study reveals common problems in mass spectrometry-based proteomics. Nat Methods 6: 423-430.
Bergeron JJ, Hallett M. 2007. Peptides you can count on. Nat Biotechnol 25: 61-62.

Bergeron JJ, Au CE, Desjardins M, McPherson PS, Nilsson T. 2010. Cell biology through proteomics — ad astra per alia porci. Trends Cell Biol 20: 337-345.

Blobel G, Dobberstein B. 1975. Transfer of proteins across membranes. I. Presence of proteolytically processed and unprocessed nascent immunoglobulin light chains on membrane-bound ribosomes of murine myeloma. $J$ Cell Biol 67: 835-851.

Blondeau F, Ritter B, Allaire PD, Wasiak S, Girard M, Hussain NK, Angers A, Legendre-Guillemin V, Roy L, Boismenu D, et al. 2004. Tandem MS analysis of brain clathrin-coated vesicles reveals their critical involvement in synaptic vesicle recycling. Proc Natl Acad Sci 101: 3833-3838.

Blouin A, Bolender RP, Weibel ER. 1977. Distribution of organelles and membranes between hepatocytes and nonhepatocytes in the rat liver parenchyma. A stereological study. J Cell Biol 72: 441-455.

Bonfanti L, Mironov AA Jr, Martinez-Menarguez JA, Martella O, Fusella A, Baldassarre M, Buccione R, Geuze HJ, Mironov AA, Luini A. 1998. Procollagen traverses the Golgi stack without leaving the lumen of cisternae: Evidence for cisternal maturation. Cell 95: 993-1003.

Bruni C, Porter KR. 1965. The fine structure of the parenchymal cell of the normal rat liver: I. General observations. Am J Pathol 46: 691-755.

Burns DM, Touster O. 1982. Purification and characterization of glucosidase II, an endoplasmic reticulum hydrolase involved in glycoprotein biosynthesis. J Biol Chem 257: 9990-10000.

Campbell-Valois FX, Trost M, Chemali M, Dill BD, Laplante A, Duclos S, Sadeghi S, Rondeau C, Morrow IC, Bell C, et al. 2012. Quantitative proteomics reveals that only a subset of the endoplasmic reticulum contributes to the phagosome. Mol Cell Proteomics 11: M111.016378.

Cebrian I, Visentin G, Blanchard N, Jouve M, Bobard A, Moita C, Enninga J, Moita LF, Amigorena S, Savina A. 2011. Sec22b regulates phagosomal maturation and antigen crosspresentation by dendritic cells. Cell 147: 13551368.

Chen Y, Hu D, Yabe R, Tateno H, Qin SY, Matsumoto N, Hirabayashi J, Yamamoto K. 2011. Role of malectin in $\operatorname{Glc}(2) \operatorname{Man}(9) \operatorname{GlcNAc}(2)$-dependent quality control of a1-antitrypsin. Mol Biol Cell 22: 3559-3570.

Cheng H, Leblond CP. 1974. Origin, differentiation and renewal of the four main epithelial cell types in the mouse small intestine. V. Unitarian theory of the origin of the four epithelial cell types. Am J Anat 141: 537-561.

Chevet E, Smirle J, Cameron PH, Thomas DY, Bergeron JJ. 2010. Calnexin phosphorylation: Linking cytoplasmic signalling to endoplasmic reticulum lumenal functions. Semin Cell Dev Biol 21: 486-490.

Christianson JC, Shaler TA, Tyler RE, Kopito RR. 2008. OS-9 and GRP94 deliver mutant $\alpha 1$-antitrypsin to the Hrd1SEL1L ubiquitin ligase complex for ERAD. Nat Cell Biol 10: $272-282$.

Claude A, Zhao BP, Kuziemsky CE, Dahan S, Berger SJ, Yan JP, Armold AD, Sullivan EM, Melancon P. 1999. GBF1: A novel Golgi-associated BFA-resistant guanine 
J. Smirle et al.

nucleotide exchange factor that displays specificity for ADP-ribosylation factor 5. J Cell Biol 146: 71-84.

Clerc S, Hirsch C, Oggier DM, Deprez P, Jakob C, Sommer T, Aebi M. 2009. Html protein generates the $N$-glycan signal for glycoprotein degradation in the endoplasmic reticulum. J Cell Biol 184: 159-172.

Cortini M, Sitia R. 2010. ERp44 and ERGIC-53 synergize in coupling efficiency and fidelity of IgM polymerization and secretion. Traffic 11: 651-659.

Cox B, Kislinger T, Emili A. 2005. Integrating gene and protein expression data: Pattern analysis and profile mining. Methods 35: 303-314.

Dahan S, Ahluwalia JP, Wong L, Posner BI, Bergeron JJ. 1994. Concentration of intracellular hepatic apolipoprotein $\mathrm{E}$ in Golgi apparatus saccular distensions and endosomes. J Cell Biol 127: 1859-1869.

Das RC, Heath EC. 1980. Dolichyldiphosphoryloligosaccharide-protein oligosaccharyltransferase; solubilization, purification, and properties. Proc Natl Acad Sci 77: 38113815.

De Duve C, Beaufay H. 1981. A short history of tissue fractionation. J Cell Biol 91: 293s-299s.

Dejgaard K, Theberge JF, Heath-Engel H, Chevet E, Tremblay ML, Thomas DY. 2010. Organization of the Sec61 translocon, studied by high resolution native electrophoresis. J Proteome Res 9: 1763-1771.

De Lorenzo F, Goldberger RF, Steers E Jr, Givol D, Anfinsen B. 1966. Purification and properties of an enzyme from beef liver which catalyzes sulfhydryl-disulfide interchange in proteins. J Biol Chem 241: 1562-1567.

Dunkley TP, Watson R, Griffin JL, Dupree P, Lilley KS. 2004. Localization of organelle proteins by isotope tagging (LOPIT). Mol Cell Proteomics 3: 1128-1134.

Ellgaard L, Helenius A. 2003. Quality control in the endoplasmic reticulum. Nature Rev Mol Cell Biol 4: 181-191.

English AR, Zurek N, Voeltz GK. 2009. Peripheral ER structure and function. Curr Opin Cell Biol 21: 596-602.

Ernster L, Siekevitz P, Palade GE. 1962. Enzyme-structure relationships in the endoplasmic reticulum of rat liver: A Morphological and Biochemical Study. J Cell Biol 15: 541-562.

Estabrook RW, Franklin MR, Cohen B, Shigamatzu A, Hildebrandt AG. 1971. Biochemical and genetic factors influencing drug metabolism. Influence of hepatic microsomal mixed function oxidation reactions on cellular metabolic control. Metabolism 20: 187-199.

Foster LJ, de Hoog CL, Zhang Y, Xie X, Mootha VK, Mann M. 2006. A mammalian organelle map by protein correlation profiling. Cell 125: 187-199.

Fraldi A, Zito E, Annunziata F, Lombardi A, Cozzolino M, Monti M, Spampanato C, Ballabio A, Pucci P, Sitia R, et al. 2008. Multistep, sequential control of the trafficking and function of the multiple sulfatase deficiency gene product, SUMF1 by PDI, ERGIC-53 and ERp44. Hum Mol Genet 17: 2610-2621.

Fujiwara T, Oda K, Yokota S, Takatsuki A, Ikehara Y. 1988. Brefeldin A causes disassembly of the Golgi complex and accumulation of secretory proteins in the endoplasmic reticulum. J Biol Chem 263: 18545-18552.

Gagnon E, Duclos S, Rondeau C, Chevet E, Cameron PH, Steele-Mortimer O, Paiement J, Bergeron JJ, Desjar- dins M. 2002. Endoplasmic reticulum-mediated phagocytosis is a mechanism of entry into macrophages. Cell 110: $119-131$.

Galli C, Bernasconi R, Solda T, Calanca V, Molinari M. 2011. Malectin participates in a backup glycoprotein quality control pathway in the mammalian ER. PLOS ONE 6: e16304.

Gannon J, Bergeron JJ, Nilsson T. 2011. Golgi and related vesicle proteomics: Simplify to identify. Cold Spring Harb Perspect Biol 3: a005421.

* Gardner BM, Pincus D, Gotthardt K, Gallagher CM, Walter P. 2013. Endoplasmic reticulum stress sensing in the unfolded protein response. Cold Spring Harb Perspect Biol doi: 10.1101/cshperspect.a 013169.

Geiger T, Wehner A, Schaab C, Cox J, Mann M. 2012. Comparative proteomic analysis of eleven common cell lines reveals ubiquitous but varying expression of most proteins. Mol Cell Proteomics 11: M111.014050.

Gilchrist A, Au CE, Hiding J, Bell AW, Fernandez-Rodriguez J, Lesimple S, Nagaya $\mathrm{H}$, Roy L, Gosline SJ, Hallett M, et al. 2006. Quantitative proteomics analysis of the secretory pathway. Cell 127: 1265-1281.

Gonzalez DS, Karaveg K, Vandersall-Nairn AS, Lal A, Moremen KW. 1999. Identification, expression, and characterization of a cDNA encoding human endoplasmic reticulum mannosidase $\mathrm{I}$, the enzyme that catalyzes the first mannose trimming step in mammalian Asn-linked oligosaccharide biosynthesis. J Biol Chem 274: $21375-$ 21386.

Grasse PP. 1957. Ultrastructure, polarity and reproduction of Golgi apparatus. C R Hebd Seances Acad Sci 245: 1278-1281 (in French).

Graumann J, Scheltema RA, Zhang Y, Cox J, Mann M. 2012. A framework for intelligent data acquisition and realtime database searching for shotgun proteomics. Mol Cell Proteomics 11: M111.013185.

Groisman B, Shenkman M, Ron E, Lederkremer GZ. 2011. Mannose trimming is required for delivery of a glycoprotein from EDEM1 to XTP3-B and to late endoplasmic reticulum-associated degradation steps. J Biol Chem 286: $1292-1300$.

Haas IG, Wabl M. 1983. Immunoglobulin heavy chain binding protein. Nature 306: 387-389.

Halter D, Neumann S, van Dijk SM, Wolthoorn J, de Maziere AM, Vieira OV, Mattjus P, Klumperman J, van Meer G, Sprong H. 2007. Pre- and post-Golgi translocation of glucosylceramide in glycosphingolipid synthesis. J Cell Biol 179: 101-115.

Hammond C, Braakman I, Helenius A. 1994. Role of Nlinked oligosaccharide recognition, glucose trimming, and calnexin in glycoprotein folding and quality control. Proc Natl Acad Sci 91: 913-917.

Hettkamp H, Legler G, Bause E. 1984. Purification by affinity chromatography of glucosidase I, an endoplasmic reticulum hydrolase involved in the processing of asparagine-linked oligosaccharides. Eur J Biochem 142: 85-90.

Hortsch M, Avossa D, Meyer DI. 1986. Characterization of secretory protein translocation: Ribosome-membrane interaction in endoplasmic reticulum. J Cell Biol 103: 241-253. 
ER-Golgi Proteomics

Houde M, Bertholet S, Gagnon E, Brunet S, Goyette G, Laplante A, Princiotta MF, Thibault P, Sacks D, Desjardins M. 2003. Phagosomes are competent organelles for antigen cross-presentation. Nature 425: 402-406.

Jamieson JD, Palade GE. 1967. Intracellular transport of secretory proteins in the pancreatic exocrine cell. I. Role of the peripheral elements of the Golgi complex. J Cell Biol 34: 577-596.

Jonikas MC, Collins SR, Denic V, Oh E, Quan EM, Schmid V, Weibezahn J, Schwappach B, Walter P, Weissman JS, et al. 2009. Comprehensive characterization of genes required for protein folding in the endoplasmic reticulum. Science 323: 1693-1697.

Kislinger T, Cox B, Kannan A, Chung C, Hu P, Ignatchenko A, Scott MS, Gramolini AO, Morris Q, Hallett MT, et al. 2006. Global survey of organ and organelle protein expression in mouse: Combined proteomic and transcriptomic profiling. Cell 125: 173-186.

Kruger M, Moser M, Ussar S, Thievessen I, Luber CA, Forner F, Schmidt S, Zanivan S, Fassler R, Mann M. 2008. SILAC mouse for quantitative proteomics uncovers kindlin-3 as an essential factor for red blood cell function. Cell 134: 353-364.

Lanoix J, Ouwendijk J, Lin CC, Stark A, Love HD, Ostermann J, Nilsson T. 1999. GTP hydrolysis by arf-1 mediates sorting and concentration of Golgi resident enzymes into functional COP I vesicles. EMBO J 18: 4935-4948.

Lanoix J, Ouwendijk J, Stark A, Szafer E, Cassel D, Dejgaard K, Weiss M, Nilsson T. 2001. Sorting of Golgi resident proteins into different subpopulations of COPI vesicles: A role for ArfGAP1. J Cell Biol 155: 1199-1212.

Lilley BN, Ploegh HL. 2004. A membrane protein required for dislocation of misfolded proteins from the ER. Nature 429: $834-840$.

Lilley BN, Ploegh HL. 2005. Multiprotein complexes that link dislocation, ubiquitination, and extraction of misfolded proteins from the endoplasmic reticulum membrane. Proc Natl Acad Sci 102: 14296-14301.

Lippincott-Schwartz J, Yuan LC, Bonifacino JS, Klausner RD. 1989. Rapid redistribution of Golgi proteins into the ER in cells treated with brefeldin A: Evidence for membrane cycling from Golgi to ER. Cell 56: 801-813.

* Lord C, Ferro-Novick S, Miller EA. 2013. The highly conserved COPII coat complex sorts cargo from the endoplasmic reticulum and targets it to the Golgi. Cold Spring Harb Perspect Biol doi: 10.1101/cshperspect.a013367.

Loud AV. 1968. A quantitative stereological description of the ultrastructure of normal rat liver parenchymal cells. J Cell Biol 37: 27-46.

Ludwig C, Claassen M, Schmidt A, Aebersold R. 2012. Estimation of absolute protein quantities of unlabeled samples by selected reaction monitoring mass spectrometry. Mol Cell Proteomics 11: M111.013987.

Lynes EM, Bui M, Yap MC, Benson MD, Schneider B, Ellgaard L, Berthiaume LG, Simmen T. 2012. Palmitoylated TMX and calnexin target to the mitochondriaassociated membrane. EMBO J 31: 457-470.

Mariappan M, Radhakrishnan K, Dierks T, Schmidt B, von Figura K. 2008. ERp44 mediates a thiol-independent retention of formylglycine-generating enzyme in the endoplasmic reticulum. J Biol Chem 283: 6375-6383.
Martinez-Menarguez JA, Geuze HJ, Slot JW, Klumperman J. 1999. Vesicular tubular clusters between the ER and Golgi mediate concentration of soluble secretory proteins by exclusion from COPI-coated vesicles. Cell 98: 81-90.

Melkonian M, Becker B, Becker D. 1991. Scale formation in algae. J Electron Microsc Tech 17: 165-178.

Miesenbock G, Rothman JE. 1995. The capacity to retrieve escaped ER proteins extends to the trans-most cisterna of the Golgi stack. J Cell Biol 129: 309-319.

Misumi Y, Miki K, Takatsuki A, Tamura G, Ikehara Y. 1986. Novel blockade by brefeldin A of intracellular transport of secretory proteins in cultured rat hepatocytes. J Biol Chem 261: 11398-11403.

Molinari M, Calanca V, Galli C, Lucca P, Paganetti P. 2003. Role of EDEM in the release of misfolded glycoproteins from the calnexin cycle. Science 299: 1397-1400.

Mori H, Christensen AK. 1980. Morphometric analysis of Leydig cells in the normal rat testis. J Cell Biol 84: 340-354.

Mosley CA, Taupenot L, Biswas N, Taulane JP, Olson NH, Vaingankar SM, Wen G, Schork NJ, Ziegler MG, Mahata SK, et al. 2007. Biogenesis of the secretory granule: Chromogranin A coiled-coil structure results in unusual physical properties and suggests a mechanism for granule core condensation. Biochemistry 46: 10999-11012.

Murphy MJ Jr, Bertles JF, Gordon AS. 1971. Identifying characteristics of the haematopoietic precursor cell. $J$ Cell Sci 9: 23-47.

Nakano A, Luini A. 2010. Passage through the Golgi. Curr Opin Cell Biol 22: 471-478.

Nilsson T, Pypaert M, Hoe MH, Slusarewicz P, Berger EG, Warren G. 1993. Overlapping distribution of two glycosyltransferases in the Golgi apparatus of HeLa cells. J Cell Biol 120: 5-13.

Nilsson T, Au CE, Bergeron JJ. 2009. Sorting out glycosylation enzymes in the Golgi apparatus. FEBS Lett 583: 3764-3769.

Novikoff PM, Yam A. 1978. The cytochemical demonstration of GERL in rat hepatocytes during lipoprotein mobilization. J Histochem Cytochem 26: 1-13.

Oda K, Hirose S, Takami N, Misumi Y, Takatsuki A, Ikehara Y. 1987. Brefeldin A arrests the intracellular transport of a precursor of complement C3 before its conversion site in rat hepatocytes. FEBS Lett 214: 135-138.

Ong SE, Blagoev B, Kratchmarova I, Kristensen DB, Steen H, Pandey A, Mann M. 2002. Stable isotope labeling by amino acids in cell culture, SILAC, as a simple and accurate approach to expression proteomics. Mol Cell Proteomics 1: 376-386.

Oprins A, Rabouille C, Posthuma G, Klumperman J, Geuze HJ, Slot JW. 2001. The ER to Golgi interface is the major concentration site of secretory proteins in the exocrine pancreatic cell. Traffic 2: 831-838.

Otte S, Belden WJ, Heidtman M, Liu J, Jensen ON, Barlowe C. 2001. Erv41p and Erv46p: New components of COPII vesicles involved in transport between the ER and Golgi complex. J Cell Biol 152: 503-518.

Ou WJ, Cameron PH, Thomas DY, Bergeron JJ. 1993. Association of folding intermediates of glycoproteins with calnexin during protein maturation. Nature 364: 771-776. 
J. Smirle et al.

Palade GE, Siekevitz P. 1956. Pancreatic microsomes; an integrated morphological and biochemical study. J Biophys Biochem Cytol 2: 671-690.

Pan S, Wang S, Utama B, Huang L, Blok N, Estes MK, Moremen KW, Sifers RN. 2011. Golgi localization of ERManI defines spatial separation of the mammalian glycoprotein quality control system. Mol Biol Cell 22:2810-2822.

Pelletier MF, Marcil A, Sevigny G, Jakob CA, Tessier DC, Chevet E, Menard R, Bergeron JJ, Thomas DY. 2000. The heterodimeric structure of glucosidase II is required for its activity, solubility, and localization in vivo. Glycobiology 10: 815-827.

Pollock S, Kozlov G, Pelletier MF, Trempe JF, Jansen G, Sitnikov D, Bergeron JJ, Gehring K, Ekiel I, Thomas DY. 2004. Specific interaction of ERp57 and calnexin determined by NMR spectroscopy and an ER two-hybrid system. EMBO J 23: 1020-1029.

Rabouille C, Hui N, Hunte F, Kieckbusch R, Berger EG, Warren G, Nilsson T. 1995. Mapping the distribution of Golgi enzymes involved in the construction of complex oligosaccharides. J Cell Sci 108: 1617-1627.

Reed JR, Backes WL. 2012. Formation of P450 · P450 complexes and their effect on P450 function. Pharmacol Ther 133: $299-310$.

Reitman ML, Trowbridge IS, Kornfeld S. 1982. A lectin-resistant mouse lymphoma cell line is deficient in glucosidase II, a glycoprotein-processing enzyme. J Biol Chem 257: 10357-10363.

Saraste J, Kuismanen E. 1984. Pre- and post-Golgi vacuoles operate in the transport of Semliki Forest virus membrane glycoproteins to the cell surface. Cell 38: 535-549.

Savitz AJ, Meyer DI. 1990. Identification of a ribosome receptor in the rough endoplasmic reticulum. Nature 346: $540-544$.

Schallus T, Jaeckh C, Feher K, Palma AS, Liu Y, Simpson JC, Mackeen M, Stier G, Gibson TJ, Feizi T, et al. 2008. Malectin: A novel carbohydrate-binding protein of the endoplasmic reticulum and a candidate player in the early steps of protein N-glycosylation. Mol Biol Cell 19: 3404-3414.

Schneider WC, Dalton AJ, Kuff EL, Felix M. 1953. Isolation and biochemical function of the Golgi substance. Nature 172: $161-162$.

Schrag JD, Bergeron JJ, Li Y, Borisova S, Hahn M, Thomas DY, Cygler M. 2001. The Structure of calnexin, an ER chaperone involved in quality control of protein folding. Mol Cell 8: 633-644.

Schrag JD, Procopio DO, Cygler M, Thomas DY, Bergeron JJ. 2003. Lectin control of protein folding and sorting in the secretory pathway. Trends Biochem Sci 28: 49-57.

Silva JC, Gorenstein MV, Li GZ, Vissers JP, Geromanos SJ. 2006. Absolute quantification of proteins by LCMSE: A virtue of parallel MS acquisition. Mol Cell Proteomics 5: $144-156$.

Smolka MB, Zhou H, Purkayastha S, Aebersold R. 2001. Optimization of the isotope-coded affinity tag-labeling procedure for quantitative proteome analysis. Anal Biochem 297: 25-31.
Stolz A, Hilt W, Buchberger A, Wolf DH. 2011. Cdc48: A power machine in protein degradation. Trends Biochem Sci 36: 515-523.

Szathmary R, Bielmann R, Nita-Lazar M, Burda P, Jakob CA. 2005. Yos 9 protein is essential for degradation of misfolded glycoproteins and may function as lectin in ERAD. Mol Cell 19: 765-775.

Taylor SC, Thibault P, Tessier DC, Bergeron JJ, Thomas DY. 2003. Glycopeptide specificity of the secretory protein folding sensor UDP-glucose glycoprotein:glucosyltransferase. EMBO Rep 4: 405-411.

Taylor SC, Ferguson AD, Bergeron JJ, Thomas DY. 2004. The ER protein folding sensor UDP-glucose glycoproteinglucosyltransferase modifies substrates distant to local changes in glycoprotein conformation. Nat Struct Mol Biol 11: 128-134.

Titorenko VI, Rachubinski RA. 1998. Mutants of the yeast Yarrowia lipolytica defective in protein exit from the endoplasmic reticulum are also defective in peroxisome biogenesis. Mol Cell Biol 18: 2789-2803.

Titorenko VI, Ogrydziak DM, Rachubinski RA. 1997. Four distinct secretory pathways serve protein secretion, cell surface growth, and peroxisome biogenesis in the yeast Yarrowia lipolytica. Mol Cell Biol 17: 5210-5226.

Trombetta ES, Parodi AJ. 2003. Quality control and protein folding in the secretory pathway. Annu Rev Cell Dev Biol 19: $649-676$.

van der Zand A, Gent J, Braakman I, Tabak HF. 2012. Biochemically distinct vesicles from the endoplasmic reticulum fuse to form peroxisomes. Cell 149: 397-409.

von Haller PD, Yi E, Donohoe S, Vaughn K, Keller A, Nesvizhskii AI, Eng J, Li XJ, Goodlett DR, Aebersold R, et al. 2003. The application of new software tools to quantitative protein profiling via isotope-coded affinity tag (ICAT) and tandem mass spectrometry: II. Evaluation of tandem mass spectrometry methodologies for largescale protein analysis, and the application of statistical tools for data analysis and interpretation. Mol Cell Proteomics 2: $428-442$.

Wahlman J, DeMartino GN, Skach WR, Bulleid NJ, Brodsky JL, Johnson AE. 2007. Real-time fluorescence detection of ERAD substrate retrotranslocation in a mammalian in vitro system. Cell 129: 943-955.

Zanetti G, Pahuja KB, Studer S, Shim S, Schekman R. 2012. COPII and the regulation of protein sorting in mammals. Nat Cell Biol 14: 20-28.

Zapun A, Petrescu SM, Rudd PM, Dwek RA, Thomas DY, Bergeron JJ. 1997. Conformation-independent binding of monoglucosylated ribonuclease B to calnexin. Cell 88: $29-38$.

Zapun A, Darby NJ, Tessier DC, Michalak M, Bergeron JJ, Thomas DY. 1998. Enhanced catalysis of ribonuclease B folding by the interaction of calnexin or calreticulin with ERp57. J Biol Chem 273: 6009-6012.

Zeiler M, Straube WL, Lundberg E, Uhlen M, Mann M. 2012. A protein epitope signature tag (PrEST) library allows SILAC-based absolute quantification and multiplexed determination of protein copy numbers in cell lines. Mol Cell Proteomics 11: O111.009613. 


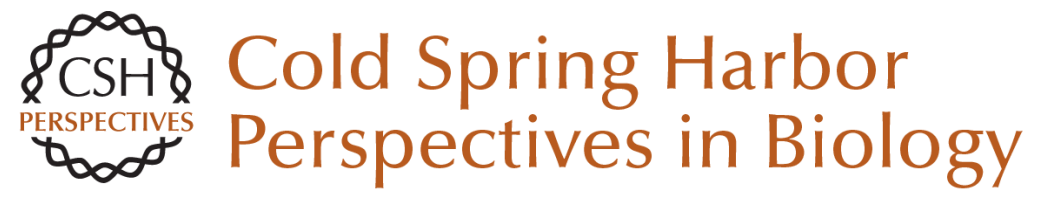

\title{
Cell Biology of the Endoplasmic Reticulum and the Golgi Apparatus through Proteomics
}

\author{
Jeffrey Smirle, Catherine E. Au, Michael Jain, Kurt Dejgaard, Tommy Nilsson and John Bergeron
}

Cold Spring Harb Perspect Biol 2013; doi: 10.1101/cshperspect.a015073

Subject Collection The Endoplasmic Reticulum

Sorting and Export of Proteins at the Endoplasmic

Reticulum

Ishier Raote, Sonashree Saxena and Vivek Malhotra

Endoplasmic Reticulum Membrane Contact Sites, Lipid Transport, and Neurodegeneration Andrés Guillén-Samander and Pietro De Camilli

AMPylation and Endoplasmic Reticulum Protein Folding Homeostasis

Luke A. Perera and David Ron

The Endoplasmic Reticulum and the Fidelity of Nascent Protein Localization

Michael J. McKenna and Sichen Shao

Endoplasmic Reticulum Architecture and

Inter-Organelle Communication in Metabolic

Health and Disease

Ana Paula Arruda and Günes Parlakgül

Regulation and Functions of the ER-Associated

Nrf1 Transcription Factor

Gary Ruvkun and Nicolas Lehrbach

Mechanism of Protein Translocation by the Sec61

Translocon Complex

Samuel Itskanov and Eunyong Park
Glycerolipid Synthesis and Lipid Droplet

Formation in the Endoplasmic Reticulum Robert V. Farese, Jr. and Tobias C. Walther

The Biogenesis of Multipass Membrane Proteins Luka Smalinskaite and Ramanujan S. Hegde

A TAle of Two Pathways: Tail-Anchored Protein Insertion at the Endoplasmic Reticulum Alina Guna, Masami Hazu, Giovani Pinton Tomaleri, et al.

Cholesterol Transport to the Endoplasmic Reticulum John P. Kennelly and Peter Tontonoz

The Role of the Rhomboid Superfamily in ER Protein Quality Control: From Mechanisms and Functions to Diseases

Satarupa Bhaduri, Nicola A. Scott and Sonya E. Neal

ER-Phagy: Quality and Quantity Control of the

Endoplasmic Reticulum by Autophagy Haruka Chino and Noboru Mizushima

Structure and Function of the Nuclear Pore

Complex

Stefan Petrovic, George W. Mobbs, Christopher J. Bley, et al.

For additional articles in this collection, see http://cshperspectives.cshlp.org/cgi/collection/

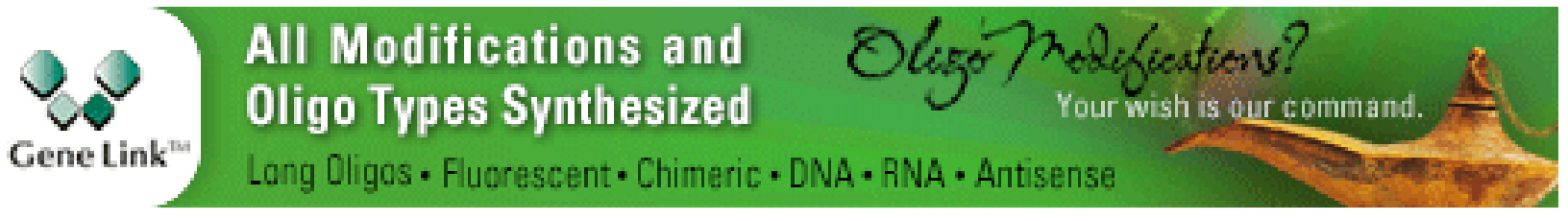




\section{Evolutionary Aspects of the Unfolded Protein Response \\ Kazutoshi Mori}

Post-Translational Regulation of HMG CoA Reductase

Youngah Jo and Russell A. DeBose-Boyd

For additional articles in this collection, see http://cshperspectives.cshlp.org/cgi/collection/

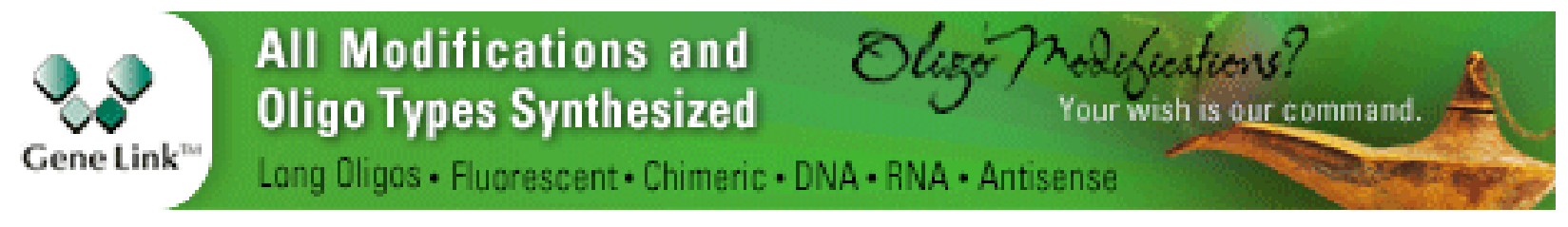

Copyright @ 2013 Cold Spring Harbor Laboratory Press; all rights reserved 